\title{
IfIISGUC.ORG
}

"İ̦, GÜç" ENDÜSTRi iLIȘKiLERI VE INSAN KAYNAKLARI DERGISi

"IS, GUC" INDUSTRIAL RELATIONS AND HUMAN RESOURCES JOURNAL

\section{Work engagement among nurses in Turkish hospitals: Potential antecedents and consequences.}

Ronald J. Burke

York University

Çetin Bektaş

Uşak University
Mustafa Koyuncu

Nevşehir University
Mehmet Tekinkuş

Gaziantep University

Lisa Fiksenbaum

York University

Ocak/January 2012, Cilt/Vol: 14, Sayı/Num:1, Page: 7-24

ISSN: 1303-2860, DOI: 10.4026/1303-2860.2012.192.x

Makalenin on-line kopyasına erişmek için:

http://www.isguc.org/?p=article\&id=478\&vol=14\&num=1\&year=2012

To reach the on-line copy of article:

http://www.isguc.org/?p=article\&id=478\&vol=14\&num=1\&year=2012

Makale İçin İletişim/Correspondence to: 
(C) 2000- 2012

“İşGüç" Endüstri İlişkileri ve İnsan Kaynakları Dergisi

"İşGüç" Industrial Relations and Human Resources Journal

\author{
Ocak/January 2012, Cilt/Vol: 14, Say1/Num: 1 \\ ISSN: 1303-2860, DOI: 10.4026/1303-2860.2012.192.x
}

\section{Editör/Editor-in-Chief \\ Aşkın Keser (Uludă̆ University)}

Editör Yardimcılari/Co-Editors

K.Ahmet Sevimli (Uludağ University)

Gözde Yilmaz (Marmara University)

Uygulama/Design

Yusuf Budak (Kocaeli Universtiy)

\author{
Yayın Kurulu / Editorial Board \\ Dr. Erdem Cam (ÇASGEM) \\ Dr. Zerrin Furat (Uludă̆ University) \\ Doç. Dr. Aşkın Keser (Uludağ University) \\ Prof. Dr. Ahmet Selamoğlu (Kocaeli University) \\ Yrd. Doç. Dr. Ahmet Sevimli (Uludăg University) \\ Doç. Dr. Abdulkadir Şenkal (Kocaeli University) \\ Doç. Dr. Gözde Yilmaz (Marmara University) \\ Dr. Memet Zencirkıran (Uludă̆ University)
}

Uluslararası Danışma Kurulu / International Advisory Board Prof. Dr. Ronald Burke (York University - CA)

Assoc. Prof. Dr. Glenn Dawes (James Cook University - AU)

Prof. Dr. Jan Dul (Erasmus University - NL)

Prof. Dr. Alev Efendioğlu (University of San Francisco - USA)

Prof. Dr. Adrian Furnham (University College London - UK)

Prof. Dr. Alan Geare (University of Otago - NZ)

Prof. Dr. Ricky Griffin (TAMU-Texas AEM University - USA)

Assoc. Prof. Dr. Diana Lipinskiene (Kaunos University - LT)

Prof. Dr. George Manning (Northern Kentucky University - USA)

Prof. Dr. William L. Murray (University of San Francisco - USA)

Prof. Dr. Mustafa Özbilgin (Brunel University - UK)

Assoc. Prof. Dr. Owen Stanley (James Cook University - AU)

Prof. Dr. Işık Urla Zeytinoğlu (McMaster University - CA)

\section{Ulusal Danışma Kurulu / National Advisory Board}

Prof. Dr. Yusuf Alper (Uludağ University)

Prof. Dr. Veysel Bozkurt (İstanbul University)

Prof. Dr. Toker Dereli (Işık University)

Prof. Dr. Nihat Erdoğmuş (Şehir University)

Doç. Dr. Mustafa Kurt (Yalova University)

Prof. Dr. Ahmet Makal (Ankara University)

Prof. Dr. Süleyman Özdemir (İstanbul University)

Prof. Dr. Ahmet Selamoğlu (Kocaeli University)

Prof. Dr. Nadir Sŭ̆ur (Anadolu University)

Prof. Dr. Nursel Telman (Maltepe University)

Prof. Dr. Cavide Uyargil (İstanbul University)

Prof. Dr. Engin Yildirım (Constitutional Court of Turkey)

Doç. Dr. Arzu Wasti (Sabancı University)

Dergide yayınlanan yazılardaki görüşler ve bu konudaki sorumluluk yazarlarına aittir.

Yayınlanan eserlerde yer alan tüm içerik kaynak gösterilmeden kullanılamaz.

All the opinions written in articles are under responsibilities of the outhors.

The published contents in the articles cannot be used without being cited. 


\title{
Work engagement among nurses in Turkish hospitals: Potential antecedents and consequences.*
}

\author{
Ronald J. BURKE \\ York University
}

\author{
Mustafa KOYUNCU Mehmet TEKINNUS \\ Nevşehir University Gaziantep University
}

Çetin BEKTAŞ

Uşak University

\author{
Lisa FIMSENBUAM \\ York University
}

\begin{abstract}
This research examined potential antecedents and consequences of work engagement in a sample of nurses employed in hospitals in Turkey. Data were collected from 224 respondents, a 37\% percent response rate, using anonymously completed questionnaires. Engagement was assessed by three scales developed by Schaufeli, Salanova, Gonzalez-Roma, and Bakker (2002): Vigor, Dedication and Absorption. Antecedents included personal demographic and work situation characteristics; consequences included measures of work satisfaction, psychological wellbeing, and perceptions of hospital functioning. The following results were observed. First, engagement, particularly dedication, predicted various work outcomes (e.g., job satisfaction, burnout). Second, engagement, particularly vigor, predicted various psychological well-being outcomes but less strongly than these predicted work outcomes. Third, engagement only predicted one aspect of hospital functioning; nurses reporting higher levels of dedication also indicated a higher quality of patient care. Organizations can increase levels of work engagement by creating supportive work experiences (e.g., control, rewards and recognition) consistent with effective human resource management practices .But caution must be exercised before employing North American practices in the Turkish context.
\end{abstract}

Keywords: work engagement, nurses employed in hospitals, effective human resource management

\footnotetext{
* Preparation of this manuscript was supported in part by the Schulich School of Business, York University and Nevşehir University. We thank the Health Ministry for their support, the hospitals for their cooperation, and our respondents for their participation.
} 
Individuals rate health care an important priority in many countries and it is likely to be even more important as the population ages. Governments devote considerable sums of money to health care to meet these needs, health care being the largest single budget item in most countries.

Nurses occupy a central role in the delivery of health care in all countries though countries have different health care systems and methods of payment options. Unfortunately research on the nursing experience carried out in some countries has indicated high levels of job dissatisfaction, burnout and intention to leave the profession (Aiken, Clarke, Sloane \& Sochalski, 2001). Many countries are facing nursing shortages, worsened by the fact that richer nations are luring nurses away from poorer ones, and that the nursing profession has lost popularity among younger women and men as a career option.. The health care system has also undergone dramatic change over the past decade stemming from the greater use of new technologies, off-shoring some services to developing countries, advances in medical knowledge, an aging population, more informed and critical users of the health care system and efforts by governments to further control health care expenditures.

Considerable research has been undertaken in various countries to understand the work experience of nurses, particularly as these relate to nurse work satisfaction, health and patient care. Much of this work, in keeping with trends at the time, has focused on "what is wrong" with hospitals more generally and with nursing more particularly. It considered issues of workload, lack of resources, lack of nursing input into decision making, overtime work, tensions between doctors and nurses, staffing shortages, and increases in abuse experienced by nursing staff as these affected burnout, depression, psychosomatic symptoms, absenteeism and intent to leave the profession (Burke, 2003; Aiken, Clarke, Sloane, Sochalski \& Silber, 2002; Aiken, Smith \& Lake, 1994; Vahey,
Aiken, Sloane, Clarke \& Vargas, 2004;Zeyjtinogly, Denton, Davie, Baumann, Blyth \& Boos, 2007 ) Most of this work used a stressor-strain framework and has added a lot to our understanding of the experiences of nurses in their workplaces and how these experience affect nurses themselves and quality of patient care. These are important understandings but tell only part of the story (Bakker, Schaufeli, Leiter \& Taris, 2008).

The emphasis on these negative experiences and outcomes was guided by the emphasis over the past sixty years on pathology and illness in the field of psychology (Myers, 2000; Peterson \& Seligman, 2003) and in the fields of organizational behavior and management over the past forty years with their emphasis on dissatisfaction, withdrawal behaviors and alienation in the workplace (Cameron, 2003; Turner, Barling \& Zacharatos, 2002). But recent developments in these fields have taken a different emphasis; an emphasis on human flourishing and individual strengths represented by the beginnings of positive psychology (Fredrickson, 1998; 2003; Seligman \& Csikszentmihalyi, 2000) and "what is right" in organizations represented by positive organizational scholarship (Cameron, Dutton \& Quinn, 2003) and positive organizational behavior (Luthans, 2002). Positive organizational scholarship focuses on positive outcomes such as resilience, meaning, thriving, engagement and excellence - the best of the human and work condition.

\section{Work engagement}

Organizations need to unleash the talents and motivations of all their employees if they are to achieve peak performance (Burke \& Cooper, 2007; Katzenbach, 2000; Ulrich, 1997). There is considerable evidence that many organizations are falling short (Burke \& Cooper, 2008a; Sirota, Mischkind \& Meltzer, 2005) however. Recent efforts to improve organizational performance have begun to emphasize positive organizational behavior concepts and positive emotions 
(Cameron, Dutton \& Quinn, 2003; May, Gilson \& Harter, 2004; Bakker \& Schaufeli, 2008).

Work engagement has emerged as the most prominent positive organizational concept, particularly among organizational consultants (Schaufeli \& Salanova, 2007, 2008). In fact practical interest in work engagement has outstripped the currently available research evidence. Issues such as what work engagement is, why it matters, how and why it benefits individuals and organizations, and if and how it can be increased, still need to be addressed.(Macey \& Schneider, 2008).

A few studies have examined work engagement among nurses in the hospital setting (e.g., Laschinger \& Leiter, 2006; Seppala, Mauno, Feldt, Hakanen, Kinnunen, Tolvanen \& Schaufeli, 2008). In addition, earlier work, though not using the terms work engagement, described hospital cultures that were associated with nurse job satisfaction and high quality patient care ( Aiken, Smith \& Lake, 1994; Leiter \& Laschinger, 2006) These hospitals were termed "magnet hospitals" and were characterized by hospital cultures that included lots of nursing staff access to information, nurse participation in decision making, doctor-nurse relationships characterized by trust, and low nurse turnover (Havens \& Aiken, 1999; Kramer, 1990).

\section{Work Engagement: Definition, Measures and Research Evidence}

Work engagement has received increasing research attention over the past ten years, reflecting this emphasis (Bakker \& Leiter, 2009;Kahn, 1992; Leiter, 2005; Schaufeli \& Bakker, 2004a; Schaufeli, Martinez, Marques-Pinto, Salanova \& Bakker, 2003). Engaged workers are energetic, are positively connected to their work and feel they are doing their jobs effectively. It is a persistent and broad affective-cognitive state. Schaufeli, Salanova, Gonzalez-Roma and Bakker (2002) view it as a positive, fulfilling work related state of mind that is characterized by vigor, dedication and absorption. Vigor is characterized by high levels of energy, the willingness to invest energy in one's work and persistence in difficult times; Dedication is characterized by high levels of work involvement and feelings of pride and challenge from one's work; and Absorption is characterized by deep concentration in one's work the sense that time passes quickly and one is reluctant to leave their work. Others have defined work engagement in slightly different but generally consistent ways (e.g., Harter, Schmidt \& Hayes, 2002; May, Gilson \& Harter, 2004; Sirota, Mischkind \& Meltzer, 2005)

The most commonly used measure of work engagement was developed by Schaufeli and his colleagues and comprises three components: vigor, dedication and absorption (Schaufeli, Salanova, Gonzalez-Roma \& Bakker, 2002). The accumulating research findings have shown that the measures of the three engagement concepts developed by Schaufeli and his colleagues (2002) are reliable, stable and valid (also see Schaufeli, Bakker \& Salanova, 2006,Schaufeli \& Salanova, 2007, 2008)..

Harter, Schmidt and Hayes (2002) found that levels of engagement were positively correlated with business-unit performance (e.g., customer satisfaction and loyalty, unit profitability, unit productivity, turnover levels and safety) in almost 8,000 business unite within 36 organizations. Engagement correlated .22 with a composite measure of performance, which increased to .38 when measurement error and restriction of range were taken into account. Salanova, Agot and Peiro (2005), in a study of front-line service workers and their customers, reported that work engagement predicted service climate which in turn predicted employee performance and then customer loyalty. Schaufeli and Salanova $(2007,2008)$, based on their review of the work engagement literature, conclude that engagement is associated with positive employee attitudes, proactive job 
behaviors, higher levels of employee psychological well-being, and increased individual job and organizational performance.

It is important to study engagement because it is linked to positive individual and work related outcomes (Schaufeli \& Salanova, 2007, 2008). The present study examines potential predictors and consequences of work engagement in a sample of nurses working in hospitals in Turkey. Turkey is currently facing a nursing shortage; similar shortages being reported in a variety of other counmtoesWhile there is some consensus on the workplace antecedents of engagement (e.g., support, feedback, coaching) and consequences of work engagement (e.g, commitment, satisfaction) , there is less agreement on personal characteristics (e.g, demographics and personality factors) associated with levels of work engagement. The question of who are engaged workers therefore needs additional attention. Schaufeli and Salanova $(2007,2008 a)$ found inconsistent or at best small effects due to demographic characteristics, and among personality factors, some evidence that individuals high on extraversion and low on neuroticism reported higher levels of work engagement. In addition, occupation type and organizational level had some effects on engagement; managers, executives and entrepreneurs score relatively high on engagement while blue collar workers, police officers and home care staff score relatively low on engagement.

The following general hypothesis, building on the reviews of Schaufeli and Salanova $(2007,2008)$ was considered: Work engagement would be positively associated with work outcomes such as job satisfaction, indicators of psychological well-being such as low levels of exhaustion and psychosomatic symptoms, and favorable perceptions of hospital functioning. To our knowledge, no other research has examined engagement among nurses in Turkey.

\section{Method}

\section{Procedure}

This study was carried out in research hospitals in Ankara Turkey, research sites being randomly selected from the 15 research hospitals in that city. The Health Ministry sent a cover letter to the Chief Physicians of these hospitals requesting their cooperation. Six hundred questionnaires were administered to staff nurses in the hospitals. Data were collected in March 2009. . Measures initially developed in English were translated into Turkish using the back translation method. Two hundred and twenty four nurses anonymously completed the surveys, a 37\% response rate The respondents are best described as a large sample of Turkish nurses working in research hospitals in Ankara Turkey.

\section{Respondents}

Table 1 presents the demographic characteristics of the sample $(n=224)$. There was considerable diversity on each item. The sample ages ranged from under 25 to over 46, with 128 between 26 and 35 (59\%), Most were married $(77 \%)$, had children $(70 \%)$, worked full-time (79\%), wanted to work fulltime $(99 \%)$, were female $(88 \%)$, worked between 41 and 45 hours per week (69\%), had a high school or vocational school education (35\%), did not have supervisory responsibilities $(68 \%)$, had not changed units in the past year $(764 \%)$, had five years or less of nursing tenure $(59 \%)$, five years of less of hospital tenure $(58 \%)$, and worked in a variety of nursing units.

\section{Measures}

\section{Work engagement}

Three aspects of work engagement were measured using scales developed by Schaufeli and his colleagues (2002) and Schaufeli and Bakker (2004a).

Vigor was measured by six items $(\alpha=.82)$. One item was "At my work I feel 


\section{Table 1}

Demographic Characteristics of Sample

\begin{tabular}{|c|c|c|c|c|c|}
\hline Age & $\mathrm{N}$ & $\%$ & $\operatorname{Sex}$ & $\underline{N}$ & $\%$ \\
\hline 25 or less & 18 & 8.4 & Female & 180 & 87.8 \\
\hline $26-30$ & 76 & 35.3 & Male & 25 & 12.2 \\
\hline $31-35$ & 52 & 24.4 & & & \\
\hline $36-45$ & 44 & 21.5 & Marital Status & & \\
\hline $41-45$ & 17 & 8.3 & Married & 168 & 77.4 \\
\hline 46 or older & 8 & 3.9 & Single & 49 & 22.6 \\
\hline$\frac{\text { Parental Status }}{\text { Children }}$ & 151 & 70.3 & $\frac{\text { Number of }}{\text { Children }}$ & & \\
\hline Childless & 64 & 29.7 & $\begin{array}{l}\overline{1} \\
2\end{array}$ & $\begin{array}{l}70 \\
76\end{array}$ & $\begin{array}{l}46.4 \\
50.3\end{array}$ \\
\hline Education & & & 3 or more & 5 & 3.3 \\
\hline$\overline{\text { High School }}$ & 75 & 34.6 & & & \\
\hline Vocational School & 50 & 23.0 & Work status & & \\
\hline Bachelor's degree & 70 & 32.2 & Full-time & 160 & 79.4 \\
\hline Master's degree & 2 & .9 & Part-time & 54 & 20.6 \\
\hline \multirow[t]{2}{*}{ Faculty } & 20 & 9.2 & & & \\
\hline & & & Supervisory & & \\
\hline Hours worked & & & Duties & & \\
\hline 40 or less & 39 & 19.8 & Yes & 69 & 31.8 \\
\hline $41-45$ & 84 & 42.6 & No & 148 & 68.2 \\
\hline $46-50$ & 38 & 18.3 & & & \\
\hline $51-55$ & 9 & 4.6 & Preferred Work & & \\
\hline \multirow[t]{2}{*}{56 or more } & 27 & 13.7 & status & & \\
\hline & & & $\overline{\text { Full-time }}$ & 197 & 99.5 \\
\hline Changed Units Past Year & & & Part-time & 1 & .5 \\
\hline$\overline{\text { Yes }}$ & 53 & 26.0 & & & \\
\hline \multirow[t]{2}{*}{ No } & 151 & 74.0 & Hospital Tenure & & \\
\hline & & & 5 years or less & 118 & 57.6 \\
\hline Nursing Tenure & & & $6-10$ years & 49 & 23.9 \\
\hline 5 years or less & 119 & 59.1 & $11-15$ years & 14 & 6.8 \\
\hline $6-10$ years & 41 & 20.4 & $16-20$ years & 15 & 7.3 \\
\hline $11-15$ years & 14 & 7.0 & 21 years or more & 9 & 4.4 \\
\hline $16-20$ years & 18 & 9.0 & & & \\
\hline 21 years or more & 9 & 4.5 & & & \\
\hline
\end{tabular}

bursting with energy". Dedication was assessed by five items $(\alpha=.79)$. An item was "I am proud of the work that I do." Absorption was measured by six items $(\alpha=85$.). One item was "I am immersed in my work". Respondents indicated their agreement with each item on a five-point Likert scale $(1=$ Strongly disagree, $3=$ Neither agree nor disagree; 5 = Strongly agree)

Personal Demographics and Work Situation $\underline{\text { Characteristics }}$

A number of personal demographics (e.g., age, gender, education, marital and parental status) and work situation characteristics (e.g. organizational level, job and organization tenure) were measured by single items (see Table 1).

A wide range of outcome variables were included in this study covering both work and extra-work domains. These variables were consistent with those typically used in studies of work and well0-being more generally (Barling, Kelloway \& Frone, 2005; Schabracq, Winnubst \& Cooper, 2003). 


\section{Work outcomes}

Job satisfaction was measured by a fiveitem scale $(\alpha=.79)$ developed by Quinn and Shepard (1974). An item was "All in all, how satisfied would you say you are with your job?". Respondents indicated their levels of satisfaction on a four-point Likert scale $(1=$ very satisfied, $4=$ not at all satisfied).

Flow was measured by a 36 item instrument $(\alpha=.91)$ developed by Jackson and Marsh (1996) This scale assessed nine dimensions: challenge-skill balance, actionawareness merging, clear goals, unambiguous feedback, concentration on task at hand, sense of control, loss of selfconsciousness, transformation, and autotelic experiences. Items included: "I felt like time stopped while I was working". Nurses were asked to identify a challenging professional work experience they had had encountered during the past few weeks and indicate how descriptive each items was of this concrete event. Respondents indicated their agreement with each item on a five point Likert scale $(1=$ strongly disagree, $3=$ neither agree nor disagree, 5 = strongly agree.

\section{Absenteeism}

Nurses indicated first how many days they had been absent from work during the past month, and then how many of these days of absenteeism wee due to sickness.

Intent to Quit ( $\alpha=.76$ ) was measured by two items (e.g., "Are you currently looking for a different job in a different organization?") using a yes/no format. This scale had been used previously by Burke (1991).

\section{Burnout}

Three dimensions of burnout were measured by the Maslach Burnout Inventory (Maslach, Jackson \& Leiter, 1996). Respondents indicated how often they experienced each item on a seven-point frequency scale $(0=$ never, $3=a$ few times a month, $6=$ every day)

Exhaustion was measured by a five-item scale $(\alpha=.86)$ An item was "I feel burnout from my work."

Cynicism was assessed by a five-item scale $(\alpha=.58)$. One item was "I have become more cynical about whether my work contributes anything."

Efficacy was measured by six items $(\alpha=.77)$ an item was "I have accomplished may worthwhile things in this job."

\section{Psychological Well-Being}

Five aspects of psychological well-being were included.

Positive Affect was measured by a ten item scale developed by Watson, Clark and Tellegen (1988). Nurses indicated how often they experienced these items during the past week (e.g., excited, proud)on a five-point Likert scale ( $1=$ not at all, $5=$ extremely often).

Negative Affect was also measured by a ten-item scale ( $\alpha=.86$ ) developed by Watson, Clark and Tellegen (1988). Respondents indicated how often they experienced these (e.g., irritable, nervous, distressed) on the same frequency scale.

Psychosomatic Symptoms was measured by nineteen items $(\alpha=.91)$ developed by Quinn and Shepard (1974). Respondents indicated how often they experienced each physical condition (e.g., headaches) in the past year on a four-point frequency scale (1 $=$ Never, $4=$ Often)

Medication use was measured by a fiveitem scale $(\alpha=.75)$ developed by Quinn and Shepard (1974). Respondents indicated how often they took listed medications (e.g., pain medication, sleeping pills) on a five-point Likert scale ( $1=$-never, $5=$ a lot).

Life satisfaction was assessed by a 5 item scale $(\alpha=.90)$ developed by Quinn and Shepard (1974). Respondents indicated their agreement with each item (e.g., In most ways my life is close to ideal") on a seven-point Likert agreement scale (1=strongly agree, $4=$ neither agree nor disagree), $7=$ strongly disagree). One item was "I am satisfied with my life." 


\section{Perceptions of Hospital functioning and Health Care}

Four measures were included here: two assessing perceptions of hospital functioning (health and safety climate, hospital errors and accidents), one assessing perceptions of patient care quality, and one measuring nurse's satisfaction being a nurse.

\section{Health and Safety Climate}

Nurses indicated their agreement with eight items $(\alpha=.74)$ based on Zohar and Luria (2005). An item was "I feel free to report safety problems where I work." Again a five-point Likert scale anchored by Strongly agree (5) and Strongly disagree (1) was used.

\section{Hospital Errors and Accidents}

Nurses indicated how frequently they observed six hospital incidents $(\alpha=-.64)$ on a four-point scale ( $1=$ never, $4=$ frequently). Incidents included: "Patient received wrong medication or dose." and "Patient falls with injuries.". This scale was created by the researchers based on previous literature.

\section{Quality of patient care}

Nurses indicated, on a single item, their views on the quality of patient care provided: "In general, how would you describe the quality of nursing care delivered to patients on your unit?" (1=Excellent, $4=$ =oor). This item was created by the researchers. Single items have been found to be highly reliable (Wanous \& Hudy, 2001).

\section{Nurse satisfaction}

Nurses indicated their satisfaction being a nurse on a single item, "Independent of your present job, how satisfied are you with being a nurse?" (1=Very dissatisfied, $4=$ Very satisfied. Again, this item was created by the researchers.

\section{Results}

\section{Descriptive Statistics}

The three work engagement measures were significantly and positive inter-correlated $(\mathrm{p}<.001$, ns range from 218 to 219): vigor and dedication,.62 .vigor and absorption,.57, and dedication and absorption,.61. These values were consistent with those reported by Schaufeli and Salanova (2007) who found these to typically be about.65. The mean values for the engagement scales among this sample of Turkish nurses, however, were significantly lower than those reported in other nursing samples and other employed populations (Seppala, Mauno, Feldt, Hakanen, Kinnunen, Tolvanen \& Schaufeli, 2008) : vigor, 3.8 ; dedication,4.0, and absorption, 3.7.

\section{Hierarchical Regression Analyses}

Hierarchical regression analyses were undertaken in which various work outcomes, indicators of psychological well-being, and perceptions of hospital functioning were separately regressed on three blocks of predictors entered in a specified order. The first block of predictors $(n=4)$ consisted of personal demographic characteristics (e.g., age, marital status, level of education), the second block of predictors $(\mathrm{N}=4)$ consisted of work situation characteristics (e.g., organizational level, organizational and job tenure), and the third block of predictors $(\mathrm{N}=3)$ were the measures of work engagement. .When a block of predictors accounted for a significant amount on increment in explained variance on a given outcome variable $(\mathrm{p}<.05)$, all measures within such blocks having significant and independent relationships with this outcome $(p<.05)$ were identified. .

\section{Predictors of Work Engagement}

Hierarchical regression analyses were first undertaken in which the three measures of work engagement were regressed on two blocks of predictors. The following comments are offered in summary. First, personal demographics accounted for a significant amount of explained variance on one measure of work engagement (vigor), but no item in this block has a significant and inde- 
pendent relationship with vigor. Second, work situation characteristics accounted for a significant increment in explained variance on all three engagement measures. Nurses who did not change units during the past years indicated higher levels of vigor, dedication and absorption (Bs=.23, .17 and .20, respectively); nurses having supervisor duties indicated higher levels of vigor $(\mathrm{B}=.20)$; nurses working part-time were more dedicated (.24), and nurses having longer unit tenure indicated higher levels of absorption (.33)

\section{Consequences of Work Engagement}

Consistent with previous research on the consequences of work engagement, indicators of work outcomes, psychological wellbeing, and perceptions of organizational functioning were included.

\section{Engagement and Work Outcomes}

Table 3 presents the results of hierarchical regression analyses in which seven work outcomes were regressed on three blocks of predictors (personal demographics, work situation characteristics, and measures of work engagement). Work engagement accounted for a significant increment in explained variance in six of the seven cases (not absenteeism). Nurses indicating higher levels of dedication also reported more job satisfaction, flow at work, and efficacy (Bs=.30, .31 and .30 , respectively) Nurses indicating higher levels of vigor also reported less exhaustion and cynicism $(\mathrm{Bs}=-.35$ and.- .23 , respectively)

\section{Engagement and Psychological Well-Being}

Table 4 shows the results of hierarchical regression analyses in which five measures of psychological well-being. were regressed on the same three blocks of predictors. The measures of work engagement accounted for a significant increment in explained variance in four of the five analyses. First, nurses indicating higher levels of vigor also reported more positive affect, more life satisfaction and fewer psychosomatic symptoms (Bs=.42, .21 and -.25 , respectively). Second, nurses indicting higher levels of dedication also reported more positive affect $(B=.20)$

Table 2

Predictors of Work Engagement

Work Engagement

Vigor ( $\mathrm{N}=167)$

Personal demographics

Work situation

Changed units (.23)

Supervisory duties (.21)

\section{Dedication ( $\mathrm{N}=165)$}

Personal demographics

Work situation

Work status (.24)

Changed units (.17)

\footnotetext{
Absorption ( $\mathrm{N}=165)$

Personal demographics

Work situation

Unit tenure (-33)

Changed units $(.20)$
}

$\begin{array}{rrrr}\underline{\mathrm{R}} & \underline{\mathrm{R}^{2}} & \underline{\Delta \mathrm{R}^{2}} & \underline{\mathrm{P}} \\ .26 & .07 & .07 & .05 \\ .41 & .17 & .10 & .001\end{array}$

NS

\section{5}

.15

.02

.02

NS

.36

.13 


\section{Table 3}

Work Engagement and Work Outcomes

Work Outcomes
Job Satisfaction( $\mathrm{N}=161)$

Personal demographics

Work situation

Supervisory duties (.18)

Engagement

Dedication(.30)

\section{Flow (N=164)}

Personal demographics

Work situation

Engagement

Dedication (.31)

Intent to Quit ( $\mathrm{N}=161$ )

Personal demographics

Marital status (-.20)

Work situation

Engagement

\section{Absenteeism ( $\mathrm{N}=162$ )}

Personal demographics

Work situation

Engagement

Exhaustion (N=162)

Personal demographics

Work situation

Engagement

Vigor (-.25)

\section{Cynicism ( $\mathrm{N}=163$ )}

Personal demographics

Work situation

Engagement

Vigor (-.23)

\section{Efficacy (N=163)}

Personal demographics

Work situation

Engagement

Dedication (.20)

$\begin{array}{rrrr}\underline{\mathrm{R}} & \underline{\mathrm{R}^{2}} & \underline{\Delta \mathrm{R}^{2}} & \underline{\mathrm{P}} \\ .22 & .05 & .05 & \mathrm{NS} \\ .34 & .12 & .07 & .05 \\ & & & \\ .47 & .22 & .10 & .001\end{array}$

$\begin{array}{llll}.18 & .03 & .03 & \text { NS }\end{array}$

$\begin{array}{llll}.27 & .07 & .04 & \text { NS }\end{array}$

$\begin{array}{llll}.46 & .21 & .14 & .001\end{array}$

$\begin{array}{llll}.37 & .14 & .14 & .001\end{array}$

$\begin{array}{llll}.42 & .18 & .04 & .001\end{array}$

$\begin{array}{llll}.50 & .25 & .07 & .001\end{array}$

$\begin{array}{llll}.09 & .01 & .01 & \text { NS }\end{array}$

$\begin{array}{llll}.13 & .02 & .01 & \text { NS }\end{array}$

$\begin{array}{llll}.29 & .08 & .06 & \text { NS }\end{array}$

$\begin{array}{llll}.25 & .06 & .06 & .05\end{array}$

$\begin{array}{llll}.32 & .10 & .04 & .05\end{array}$

$\begin{array}{llll}.50 & .25 & .15 & .05\end{array}$

$\begin{array}{llll}.14 & .02 & .01 & \text { NS } \\ .29 & .09 & .07 & \text { NS } \\ .46 & .21 & .12 & .001\end{array}$

$\begin{array}{lrrr}.11 & .01 & .01 & \text { NS } \\ .26 & .06 & .05 & \text { NS } \\ .46 & .21 & .15 & .001\end{array}$


Table 4

Engagement and Psychological Well-Being

\begin{tabular}{|c|c|c|c|c|}
\hline Psychological Well-Being & $\underline{\mathrm{R}}$ & $\underline{R^{2}}$ & $\underline{\Delta R^{2}}$ & $\underline{P}$ \\
\hline \multicolumn{5}{|l|}{ Positive Affect (N=161) } \\
\hline Personal demographics & .13 & .02 & .02 & NS \\
\hline Work situation & .26 & .07 & .05 & NS \\
\hline Engagement & .52 & .28 & .21 & .001 \\
\hline \multicolumn{5}{|l|}{ Vigor (.42) } \\
\hline \multicolumn{5}{|l|}{ Dedication $(.20)$} \\
\hline \multicolumn{5}{|l|}{ Negative Affect $(\mathrm{N}=160)$} \\
\hline Personal demographics & .15 & .02 & .02 & NS \\
\hline Work situation & .28 & .08 & .06 & NS \\
\hline Engagement & .38 & .14 & .06 & .05 \\
\hline \multicolumn{5}{|c|}{ Psychosomatic Symptoms (N=184) } \\
\hline Personal demographics & .24 & .06 & .06 & NS \\
\hline Work situation & .32 & .10 & .04 & .05 \\
\hline Engagement & .42 & .18 & .08 & .001 \\
\hline \multicolumn{5}{|l|}{ Vigor $(-.25)$} \\
\hline \multicolumn{5}{|l|}{ Medication Use $(\mathrm{N}=162)$} \\
\hline Personal demographics & 16 & .03 & .03 & NS \\
\hline Work situation & .21 & .04 & .01 & NS \\
\hline Engagement & .30 & .09 & .05 & NS \\
\hline \multicolumn{5}{|l|}{ Life satisfaction ( $\mathrm{N}=162)$} \\
\hline Personal demographics & .14 & .02 & .02 & NS \\
\hline Work situation & .21 & .04 & .02 & NS \\
\hline Engagement & .38 & .14 & .10 & .001 \\
\hline Vigor (.21) & & & & \\
\hline
\end{tabular}

\section{Engagement and Perceptions of Hospital} functioning

Table 5 shows the results of hierarchical regression analyses in which five indicators of hospital functioning were separately regressed on the same three blocks of predictors. The following comments are offered in summary. First, work engagement accounted for a significant increment in explained variance in two of the five analyses (health and safety climate and satisfaction with being a nurse) but work engagement scales only had significant and independent relati- onships with satisfaction being a nurse. Nurses indicating higher levels of dedication also reported higher levels of satisfaction being a nurse $(\mathrm{B}=.43)$.

Some other observations across these tables are worth noting. First, work engagement had the strongest relationships with work outcomes. Second, both dedication and vigor has significant relationships with various outcome variables, absorption did not had any significant and independent relationships with these same outcomes Third, work engagement had the weakest relati- 
Table 3

Engagement and Hospital Functioning

$\begin{array}{lcccc}\text { Hospital Functioning } & \underline{\mathrm{R}} & \underline{\mathrm{R}^{2}} & \underline{\Delta \mathrm{R}^{2}} & \underline{\mathrm{P}} \\ \begin{array}{l}\text { Health and Safety } \\ \text { Climate (N=163) }\end{array} & .10 & .01 & .01 & \mathrm{NS} \\ \quad \text { Personal demographics } & .24 & .06 & .05 & \mathrm{NS} \\ \quad \text { Work situation } & .35 & .12 & .06 & .05 \\ \quad \text { Engagement } & & & & \\ & & & & \\ \text { Hospital Errors and Accidents (N=158) } & .15 & .02 & .02 & \mathrm{NS} \\ \quad \text { Personal demographics } & .18 & .03 & .01 & \mathrm{NS} \\ \quad \text { Work situation } & .26 & .07 & .04 & \mathrm{NS} \\ \text { Engagement } & & & & \\ & & & & \\ \text { Quality of Health Care (N=160) } & .24 & .06 & .06 & .05 \\ \quad \text { Personal demographics } & .25 & .06 & .00 & \mathrm{NS} \\ \quad \text { Work situation } & .30 & .09 & .03 & \mathrm{NS} \\ \quad \text { Engagement } & & & & \\ \text { Satisfaction as a Nurse (N=165) } & & & & \\ \quad \text { Personal demographics } & .12 & .01 & .01 & \mathrm{NS} \\ \quad \text { Work situation } & .23 & .05 & .04 & \mathrm{NS} \\ \quad \text { Engagement } \quad .52 & .27 & .22 & .001 \\ \quad \text { Dedication (.43) } & & & & \end{array}$

onships with nurse perceptions of hospital functioning. Hospital functioning is likely affected by several variables, work engagement being only one of these, and perhaps less important than other variables.

\section{Discussion}

This research examined potential antecedents and consequences of work engagement in a large sample of nurses working in hospitals in Turkey. An increasing number of organizations are concluding that they need to unleash the untapped potential of all their employees if they are to compete successfully in an increasingly demanding global market place (Burke \& Cooper, 2008, Lawler, 2008). Our data indicated that levels of work engagement among our nursing sample were significantly lower than other normative groups (e.g., Seppala, Mauno,
Teldt, Hakanen, Kinnunen, Tolvanen \& Schaufeli, 2008) suggesting a potential concern for their employing hospitals. The results indicated that while personal demographic and work situation characteristics were moderately related to levels of work engagement.(see Table 2) Work engagement, in turn, was found to have fairly consistent, but moderate, relationships with several work outcomes and indicators of psychological well-being (see Tables 3, 4 and 5). Engagement, it seems, has potentially positive consequences for both employees and their employing organizations.

\section{Practical Implications}

The accumulating research findings on work engagement have added considerably to our understanding of implications for building more effective organizations. The re- 
search that has considered the organizational environment associated with high levels of work engagement has reported that organizational support plays a central role (Demerouti, Bakker, deJonge, Janssen \& Schaufeli, 2001). Fortunately there is some understanding of the processes on mechanisms that underlay levels of support.

Leiter (2005) offers a comprehensive look at interventions in the workplace designed to enhance engagement with work. Increasing engagement with work is a challenging and complex undertaking. As the research findings show, engagement stems from the employees contact with a work environment.

Leiter offers a conceptual framework to build engagement with work that considers the targets of intervention, strategies for intervention and potential consequences. Intervention targets include energy at work, involvement with one's work, and efficacy at work. Intervention strategies involve both individuals and organizational or workplace levels. It is critical to remember that individuals have different views and values about work-which can change over time - and that employees must participate in building engagement at work.

Schaufeli and Salalnova $(2007,2008)$ suggest a number of ways to build work engagement. These include:

* enhancing the person-job fir

* matching individual and organizational needs

* developing a meaningful psychological contract that links personal goals of individual employees with organizational resources.

* surveys of employee demands and resources and their association with positive and negative outcomes

* job redesign that reduces stressors and increases resources

* leadership development that build a po- sitive emotional climate in the workplace

* developing training programs that are targeted at both organizational health and individual well-being.

Our findings suggest that engagement at work is associated with positive work and individual well-being outcomes and that stable individual difference factors are a major contributor to levels of employee engagement. They are consistent with the results of an increasing number of recent studies (Gonzalez-Roma, Schaufeli, Bakker \& Lloret, 2006; Hakanen, Bakker \& Demerouti, 2005; Langelaan, Bakker, von Doornen \& Schaufeli, 2006; Montgomery, Peeters, Schaufeli \& Den Ouden, 2003) reflecting the importance of understanding and increasing employee engagement. Our findings extend our understand of engagement in ways that have practical implications such as those proposed by Schaufeli and Salanova (2007) who suggest that selection, goal setting and the articulation of a challenging "contract" between the individual and the organization are ways to heighten engagement. This emphasis fits with the recognition that people and organizational culture may be the real competitive advantage held by organizations (Pfeffer, 1994, 1998 Sisodia, Wolfe \& Sheth, 2007).

\section{A word of caution}

The individual and organizational benefits of work engagement found in this sample of Turkish nurses replicates results obtained in several other countries (See Schaufeli \& Salanova, 2007, for a review). Human resource management (HRM) initiatives designed to increase work engagement have typically been proposed for the highly developed countries in the world (US, Canada, the Netherlands). There is evidence (Hofstede, 1980) that the societal and cultural values of Turkey, though changing and moving slowly towards those in the West, are different from those in Western developed countries. Some Turkish writers 
(Aycan, 2001, Wastli, 1999) have cautioned against the direct application of Western approaches to Turkey. We believe these cautions should be heeded. Aycan (2001) suggests that greater attention be paid to adapting Western-based HRM practices to the Turkish culture and values and/or preparing Turkish employees for the introduction of Western HRM practices.

\section{Limitations}

This research has some limitations. First, all data were collected using self-report questionnaires raising the possibility of responses being affected by a common-method. Second, the data were collected at one point in time making it difficult to establish causal relationships. Third, a few of the measures had levels of internal consistency reliability below the generally accepted level of .70. Fourth, the nursing sample was relatively small and tended to be young with little nursing experience; the extent to which these findings generalize to other nursing samples in other countries is not clear.

\section{Future Research Directions}

Future research should include a larger sample of nurses from more hospitals, including nurses who are older and have more nursing experience. It would also be informative to include individual-based indicators of hospital functioning such as self-rated job performance, proactive behaviors, and organizational citizenship behaviors rather than indicators of hospital-wide functioning. Individual work engagement is more likely to be an outcome of these hospital-wide indicators of functioning than a cause of them.

\section{References}

Aiken, L. H., Smith, H. L., \& Lake, E. T. (1994) Lower medicate mortality among a set of hospitals known for good nursing care. Medical Care, 32, 771-787.

Aiken, L. H., Clarke, S. P., Sloane, D. M. \& Sochalski, J. (2001) Nurses' reports on hospital care in five countries. Health Affairs, 20, 343-353.

Aiken, L. H., Clarke, S. P., Sloane, D. M., Sochalski., J. \& Silber, J. H. (2002) Hospital nurse staffing and patient mortality, nurse burnout and job dissatisfaction. Journal of the American Medical Association, 288, 1987-1993.

Aycan, Z. (2001) Human resource management in Turkey: Current issues and future challenges. International Journal of Manpower. 22, 252-260

Bakker, A. B. (2009) Building engagement in the workplace. In R. J. Burke \& C. L. Cooper (eds.) The peak performing organization. London: Routledge, pp.50-72.

Bakker, A. B., \& Leiter, M. P. (2010) Work engagement. London: Psychology Press.

Bakker, A. B., \& Schaufeli, W. B. (2008) Positive organizational behavior: Engaged employees in flourishing organizations. Journal of Organizational Behavior, 29, 147-154.

Bakker, A B., Schaufeli, W. B., Leiter, M. P., \& Taris, T. W. (2008) Work engagement: An emerging cncept in organizational health psychollgy. Work And /Stress, 22, 187200.

Barling, J. Kelloway, E. K. \& Frone, M. R. (2005) Handbook of work stress. Thousand Oaks, CA: Sage Publications.

Burke, R. J, \& Cooper, C. L (2008) The peak performing organization. 
Burke, R. J, \& Cooper, C. L. (2007) Building more effective organizations. Cambridge, UK: Cambridge University Press.

Burke, R. J. (2003) Length of shift, work outcomes, and psychological well-being of nursing staff. International Journal of Public Administration, 26, 1637-1646.

Burke, R.J. (1991) Early work and career experiences of female and male managers and professionals: Reasons for optimism? Canadian Journal of Administrative Sciences, 8, 224-230.

Cameron, K. S. (2003) Organizational virtuousness and performance. In K.S. Cameron, J. E. Dutton \& R..E. .Quinn (eds.) Positive organizational scholarship. San Francisco: Berrett-Koehler. pp. 48-65.

Cameron, J., Dutton, J. \& Quinn, R.E. (2003) Positive organizational scholarship. San Francisco: Berrett-Koehler.

Demerouti, E., Bakker, A.B., deJonge, J., Janssen, P.P.M., \& Schaufeli, W.B. (2001) Burnout and engagement at work as a function of demands and control. Scandinavian Journal of Work, Environment and Health, 27, 279-286.

Fredrickson, B. L. (2003) The value of positive emotions. American Scientist, 91, 330335.

Fredrickson, B. L. (1998) What good are positive emotions? Review of General Psychology, 2, 300-3319.

Gonzalez-Roma, V., Schaufeli, W.B., Bakker, A.B., \& Lloret, S. (2006) Burnout and work engagement: Independent factors or opposite poles? Journal of Vocational Behavior, 68, 165-174.

Hakanen, J.J., Bakker, A.B., Demerouti, E. (2005) How dentists cope with their job demands and stay engaged: the moderating role of job resources. European Journal of Oral Science, 113, 479-487.

Harter, J. K., Schmidt, F. L., \& Hayes, T. L
(2002) Business-unit level relationship between employee satisfaction, employee engagement and business outcomes: A meta-analysis,. Journal of Applied Psychology, 87, 268-279.

Havens, D. S.,. \& Aiken,L. H. (1999) Shaping systems to promote desired outcomes: The magnet hospital model. Journal of Nursing Administration, 29, 14-20.

Hofstede, G. (1980) Culture's consequences: International differences in work-related values. Beverly Hills, CA: Sage Publications.

Jackson, S. A., \& Marsh, H. W. (1996) Development and validation of a scale to measure optimal experience: The flow State Scale. Journal of Sport and Exercise Psychology, 18, 17-35.

Kahn, W.A. (1992) To be fully there; Psychological presence at work. Human Relations, $45,321-349$.

Katzenbach, J.R. (2000) Peak performance: Aligning the hearts and minds of your employees. Boston: Harvard Business School Press.

Kramer, M. (1990) The magnet hospitals: Excellence revisited. Journal of Nursing Administration, 20, 25-30.

Langelaan, S., Bakker, A.B., van Doornen, L.J.P., \& Schaufeli, W.B. (2006) Burnout and work engagement: Do individual differences make a difference? Personality and Individual Differences, 40, 521532.

Laschinger, , H. K. S. \& Leiter, M. P. (206) The impact of nursing work environments on patient safety outcomes: The mediating role of burnout/engagement. Journal of Nursing Administration, 5, 259-267.

Lawler, E E. (2008) Talent: Making people your competitive advantage. San Francisco: Jossey Bass. Lawler, E.E. (2003) Treat people right. San Francisco: JosseyBass. 
Leiter, M.P. (2005) Engagement with work: Issues for measurement and intervention. In R.J. Burke \& C.L. Cooper (eds.) The human resources revolution: Why putting people first matters. Oxford; Elsevier, pp. 213-230.

Leiter, M. P., \&Laschinger, H. K. S. (2006) a work environment to support professional nursing practice: Implications for burnout. Nursing Research, 55, 137-146.

Luthans, F. (2002) Positive organizational behavior: Developing and managing psychological strengths. Academy of Management Executive, 16, 57-72.

Macey, W. H., \& Schneider, B. (2008) The meaning of employee engagement. Industrial and Organizational Psychology, 1, 3-30.

Maslach, C., Jackson, S.E., \& Leiter, M.P. (1996) Maslach Burnout Inventory, 3rd, ed. Palo Alto, CA: Consulting Psychologists Press.

Mauno, S., Pykko, M., \& Hakanen, J. (2005) The prevalence and antecedents of work engagement in three different organizations. Psykologia, 40, 16-30.

May, D.R., Gilson, R.L., \& Harter, L.M. (2004) The psychological conditions of meaningfulness, safety and availability and the engagement of the human spirit at work. Journal of Occupational and Organizational Psychology, 77, 11-37.

Montgomery, A.J., Peeters, M.C.W., Schaufeli, W.B., \& Den Ouden, M. (2003) Workhome interference among newspaper managers: Its relationship with burnout and engagement. Anxiety, Stress \& Coping: An International Journal, 16, 195211

Myers, D. G. (2000) The funds, friends and faith of happy people. American Psychologist, 55, 56-67.

Peterson, C.M., \& Seligman, M. F. P. (2003) Positive organizational studies: Lessons from positive psychology. In K. s. Cameron, J. E. Dutton \& R. E. Quinn (eds.) Po- sitive organizational scholarship. San Francisco: Berrett-Koehler. pp. 14-28.

Pfeffer, J. (1994) Competitive advantage through people. Boston: Harvard Business School Press.

Pfeffer, J. (1998) The human equation: Building profits by putting people first. Boston: Harvard Business School Press.

Quinn, R.P. \& Shepard, L.J. (1974) The 197273 Quality of Employment Survey, Ann Arbor, MI: Institute Social Research, University of Michigan.

Salanova, M., \& Schaufeli, W. B. (2008) A cross-national study of work engagement as a mediator between job resources and proactive behavior. International Journal of Human Resources Management, 129, 116-131.

Salanova, M., Agut, S. \& Peiro, J.M. (2005) Linking organizational resources and work engagement to employee performance and customer loyalty: The mediation of service climate. Journal of Applied Psychology, 96, 1217-1227.

Schabracq, M.. J., Winnubst, J. A. M., \& Cooper, C. L. (2003) The handbook of work and health psychology. West Sussex, UK: John Wiley.

Schaufelif, W. B. \& Salanova, M., (2008) Enhancing work engagement through the management of human resources. pp. 380- 402 .

Schaufeli, W. B., \& Salanova, M., (2007) Work engagement: An emerging psychological concept and its implications for organizations. In S. W.Gillilalnd, S, W,.Steiner \& D. P. Skarlicki (eds). Managing social and ethical issues in organizations. Greenwich,CT: Information Age Publishing. pp. 135-177.

Schaufeli, W.B. \& Bakker, A.B. (2004b) Job demands, job resources, and their relationship with burnout and engagement: a multi-sample study. Journal of Organizational Behavior, 25, 293-515. 
Schaufeli, W.B. \& Bakker, A.B. (2004a) Work engagement and the measurement of a concept. Gedrag-en-Organisatie, 17, 89112.

Schaufeli, W.B., Bakker, A. \& Salanova, M. (2006) The measurement of work engagement with a short questionnaire: a cross-national study. Educational and Psychological Measurement, 20, 1-16.

Schaufeli, W.B., Martinez, I .M., MarquesPinto, A., Salanova, M., \& Bakker, A.B. (2003) Burnout and engagement in university students: A cross-national study. Journal of Cross-Cultural Psychology, 33, 464-481.

Schaufeli, W.B., Salanova, M., GonzalezRoma, V., \& Bakker, A.B. (2002) The measurement of engagement and burnout: A two simple confirmatory factor analytic approach. Journal of Happiness Studies, 3, 71-92.

Seligman, M. E. P., \& Csikszentmihalyi, M. (2000) Positive psychology: An introduction. American Psychologist, 55, 5-14.

Seppala, P., Mauno, S., Feldt, T., Hakanen, J., Kinnunen, U., Tolvanen, A., \& Schaufeli, W. (2008) The construct validity of the Utrecht Work Engagement Scale: Multisample and longitudinal evidence. Journal of Happiness Studies, 10, 459-481.

Sirota, D., Mischkind, L.A., \& Meltzer, M.I. (2005) The enthusiastic employee: How companies profit by giving workers what they want. Philadelphia, PA: Wharton School Publishing.

Sisodia, R., Wolfe, D. B., \& Sheth, J. (2007) Firms of endearment: How world-class companies profit from passion and purpose. Philadelphia: Wharton School Publishing

Turner, N., Barling J., \& Zacharatos, A. (2002) Positive psychology at work. In C. Snyder \& S. Lopez (eds.) The handbook of positive psychology. Oxford: Oxford University Press. pp. 715-730.
Ulrich, D. (1997) Human resource champions. Boston: Harvard Business School Press.

Vahey, D. C., Aiken, L. H., Sloane, D.M., Clarke, S.P., \& Vargas. D. (2004) Nurse burnout and patient satisfaction. Medical Care, 42, 1157-1166.

Wanous, J. P., \& Hudy, M. (2001) Single-item reliability: A replication and extension. Organizational Research Methods, 4, 361-375.

Wasti, S. A. (1998) Cultural barriers in the transferability of Japanese and American human resources practices to developing countries: The Turkish case. International Journal of Human Resources Management,9, 608-631.

Watson, DE., Clarke, L. A., \& Tellegen, A. (1988) Development and validation of brie measures of positive and negative affect: The PANAS scales. Journal of Personality and Social Psychology, 54, 10631070.

Zeytinoglu, I. U., Denton, M., Davies, s. Baumann, A., Blythe, J., \& Boos, L (2007) Deteriorated external work environment, heavy workload and nurses' job satisfaction and turnover intention. Canadian: Public Policy, 33, S31-S47.

Zohar, D., \& Luria, G. (2005) A multi-level model of safety climate: Cross-level relationships between organizations and group-level climates. Journal of Applied Psychology, 90, 616-628. 